\title{
Närståendes erfarenheter av ett palliativt hemsjukvårdsteam
}

FÖRFATTARE

FRISTÅENDE KURS
Ingbritt Borstrand

Omvårdnad -

Självständigt arbete II

VEA010

VT 2008

OMFATTNING

$15 \mathrm{Hp}$

HANDLEDARE

EXAMINATOR
Linda Berg

Karin Ahlberg

Sahlgrenska akademin VID GÖTEBORGS UNIVERSITET Institutionen för vårdvetenskap och hälsa 
Titel (svensk)

Titel (engelsk)

Arbetets art:

Arbetets omfattning:

Sidantal:

Författare:

Handledare:

Examinator:
Närståendes erfarenheter av ett palliativt hemsjukvårdsteam.

Next-of-kin's experiences from a palliative home nursing team.

Omvårdnad- Självständigt arbete II

15 högskolepoäng

28 sidor

Ingbritt Borstrand ingbritt.borstrand@hogsbo.goteborg.se

Linda Berg

Karin Ahlberg

\section{ABSTRAKT}

Introduktion Utbyggnaden av avancerad hemsjukvård har ökat och tidigare forskning visar att många människor vill dö i sitt eget hem. Närstående är betydelsefulla i omvårdnaden, men det är känslofyllt och krävande för närstående som behöver stöd.

Syfte Studiens syfte var att belysa närståendes erfarenheter av ett palliativt hemsjukvårdsteam.

Metod Intervjustudie med 13 närstående till patienter som hade vårdats hemma till livets slut med hjälp av ett palliativt hemsjukvårdsteam. En kvalitativ innehållsanalys användes vid analysen.

Resultat Att närstående var tacksamma för tryggheten men upplevde utsatthet framträdde som ett övergripande tema. Sex kategorier kunde identifieras: Att förlita sig på vårdarna, att bli inbjuden och få stöd i vårdandet, att dela ansvaret med teamet, att inte vara införstådd, att uppleva påfrestningar, att få stöd efter vårdtiden.

Diskussion Trots att närstående var mycket nöjda, de upplevde trygghet och hade stort förtroende till teamet, framkom brister. Teamets insatser räckte inte till alla gånger, vilket bekräftas i tidigare forskning.

Slutsats Då alla är unika, såväl patient som närstående, och därmed har olika behov av palliativa teamet är det viktigt att detta uppmärksammas. Teamet måste ha de resurser som krävs och kunna ge individanpassade insatser och stöd för att ge god palliativ vård $i$ hemmet.

Nyckelord: omvårdnad, hemsjukvård, närstående, palliativt team, palliativ vård 
BAKGRUND

Inledning ___ 4

Vårdteamet i palliativ hemsjukvård___ 4

Studiens palliativa team _ 5

Närstående i palliativ hemsjukvård _ـ 5

Teoretisk anknytning ___ 8

Problemformulering__ 8

SYFTE__ 9

METOD

Kvalitativ ansats _ـ 9

Urval och procedur

Intervjun _ 10

Kvalitativ innehållsanalys _ـ 10

Etiska övervägande

RESULTAT — 12

Övergripande tema — 12

Att förlita sig på vårdarna i teamet _ 13

Att bli inbjuden och få stöd i vårdandet___ 14

Att dela ansvaret med teamet ___ 15

Att inte vara införstådd ___ 17

Att uppleva påfrestningar __ 17

Att få stöd efter vårdtiden _ 19

DISKUSSION__ 20

Metoddiskussion__ 20

Resultatdiskussion — 21

Närstående förlitade sig på vårdarna i teamet __ 21

Närstående var tacksamma för tryggheten _ 22

Närståendes erfarenheter av att dela ansvaret med teamet___ 22

Närstående upplevde utsatthet ___ 23

Närstående hade ytterligare behov av stöd __ 24

Reflektioner___ 24

Slutsats

REFERENSER _ 26

Bilaga 1 


\section{BAKGRUND}

\section{Inledning}

Att vara nära närstående till en döende person är ofta en svår situation. Det kan vara första gången som den närstående ställs inför döende och död. Många närstående anser det är självklart att leva nära den sjuke och ta ansvar samtidigt som de ska hantera både sin egen och den sjukes sorg (Andershed 2004). Närvaro av närstående är ofta nödvändigt för att få en lyckad palliativ vård i hemmet och vårdarnas förmåga att stödja de närstående är betydelsefull för att de ska klara av den påfrestande situationen (Millberg \& Strang 2004). Exley och Tyrer (2005) fann att det var känslofyllt, fysiskt krävande och uttröttande för närstående att vårda den sjuke trots att de var mycket nöjda med hjälpen och stödet de fick i hemmet. Sedan flera år arbetar författaren som distriktssköterska i ett palliativt hemsjukvårdsteam i västra Sverige. De senaste åren har författaren allt mer uppmärksammat närståendes situation i samband med vården till patienten i hemmet. Närstående gör en fantastisk insats för att patienten ska kunna vårdas hemma. Patient och närstående är dock i regel i behov av stöd och insatser från palliativa teamet. Men är insatserna och stödet till patient och närstående tillräckligt utifrån närståendes perspektiv?

\section{Vårdteamet i palliativ hemsjukvård}

Världshälsoorganisationen (WHO) definierar palliativ vård som ett förhållningssätt för att förbättra livskvaliteten för patienten och närstående genom att förebygga och lindra lidandet genom att tidigt upptäcka, bedöma och behandla smärta och andra fysiska, psykosociala och andliga problem som kan förekomma i samband med en livshotande sjukdom. Den palliativa vården betraktar liv, döende och död som normala processer (WHO 2002). De fyra hörnstenarna i den palliativa vården bygger på symtomlindring, teamsamverkan, god kommunikation och relation mellan patient, närstående och personalen samt att ge stöd till närstående både under och efter vårdtiden (Socialstyrelsen 2006).

Enligt Socialstyrelsen (2006) definieras hemsjukvård som "hälso och sjukvård när den ges i en patients bostad eller motsvarande och där ansvaret för de medicinska åtgärderna är sammanhängande över tiden. Åtgärder/insatser ska ha föregåtts av vård och omsorgsplanering"(s 35). De medicinska insatserna i hemmet omfattar hälso- och sjukvårdsinsatser som utförs av vårdteamet. Den avancerade hemsjukvården är läkarledd och det är vanligt att den organiseras som en del i länssjukvården eller inom primärvården med koppling till vårdcentraler. Palliativ vård är oftast en del av den avancerade hemsjukvården (Socialstyrelsen 2006).

För att kunna erbjuda god vård till livets slut i hemmet måste en del kriterier uppfyllas. Patient och eventuella närstående ska vara överens om att vården ska ske i hemmet. Ekonomiskt stöd till närstående ska kunna ges. Det ska finnas en välfungerande hemtjänstorganisation och effektiv tillgång till hjälpmedel. Vårdteamet ska ha hög kompetens och läkarmedverkan och kvalificerad vård ska kunna ges dygnet runt. Det ska finnas möjlighet till slutenvård om vården i hemmet inte längre är önskvärd eller lämplig (Beck-Friis \& Österberg 2005). 
God palliativ vård förutsätter ett teamarbete där läkare, sjuksköterska, undersköterska, arbetsterapeut, sjukgymnast, kurator, diakon med flera ska kunna ingå eller bli konsulterade allt efter patientens behov (Socialstyrelsen 2006). Det multiprofessionella teamet samverkar inbördes för att utnyttja vårdarnas olika kompetens och möjligheter i vården av patienten. Regelbundna teamträffar där det diskuteras hur vården ska läggas upp med tydliga mål är en förutsättning för teamarbetet. Om det brister i teamsamarbetet och i vårdorganisationen är det inte ovanligt att patient och närstående upplever att det saknas mål och att organisationen är rörig vilket kan orsaka lidande för patienten (Eckerdahl 2003). Kommunikationen inom teamet måste vara av sådan art att alla förändringar beträffande mål eller behandlingar är kända av alla oavsett om personalen arbetar på dagen eller natten. Det måste även finnas en öppen kommunikation om döende, död och sorg mellan de olika professionerna. Om vårdarna inte har bearbetat frågan om sin egen död finns begränsade möjligheter att ge patienten den helhetsvård som hon/han har rätt till (Gunnars 1996).

Att arbeta med palliativ vård innebär många påfrestningar för vårdarna, som involveras i känslomässiga konflikter och får ta emot den vrede som kan uttryckas av patienter och närstående. Teamet måste hantera nederlag i den medicinska behandlingen och upprepade erfarenheter av att personer som det har skapats en relation till avlider. För att kunna bevara sin fysiska och känslomässiga hälsa och undvika utbrändhet är det viktigt att teamet har delat ansvar och tar gemensamma beslut. Vidare är det väsentligt för att kunna vårda sig själv, att som vårdare ha medkänsla, flexibilitet, humor och fantasi. Teamets medlemmar måste också kunna acceptera misstag liksom förmåga att rätta till dem och ha psykologisk beredskap för att anta utmaningar (Twycross 1998). Teamet måste få tillgång till kontinuerlig fortbildning och handledning då arbetet är så kvalificerat, kunskapskrävande och emotionellt påfrestande. Att arbeta med palliativ vård är en fråga om relationer då man ömsom ger och ömsom får vård. Det är viktigt med en medveten personalledning i den palliativa vården (Beck-Friis \& Österberg 2005).

\section{Studiens palliativa team}

Där föreliggande studie genomfördes består det palliativa hemsjukvårdsteamet av sjuksköterskor, läkare, undersköterskor, arbetsterapeut, sjukgymnast samt kurator. Övervägande delen av personalen är sjuksköterskor som alla har flerårig erfarenhet från palliativ vård. Palliativ omvårdnad ges dygnet runt av sjuksköterskor och undersköterskor, övrig personal arbetar dagtid måndag till fredag. Det palliaitiva hemsjukvårdsteamet har ett upptagningsområde på cirka 100000 invånare i västra Sverige. Antalet inskrivna kan variera mellan ca 65-85 patienter med en vårdtid från någon vecka till flera år. Resvägen mellan olika patienter kan vara upp till cirka fyra mil. Det palliativa teamet kan nås av patient och närstående direkt via mobiltelefon dygnet runt.

\section{Närstående i palliativ hemsjukvård}

Begreppet närstående används alltmer som ersättning för anhörig i vetenskaplig litteratur. Närstående ger en vidare association till vårdtagarens närmaste sociala situation. Det kan t ex vara en granne, en vän eller någon släkting (Östlinder 2004). 
Flera studier visade att det var vanligt att närstående ville fullfölja den sjukes önskan om att få avsluta sitt liv hemma (Wennman \& Tishelman 2002, Exley \& Tyrer, 2005, Stajduhar \& Davies 2005). Perreault et al (2004) har visat att närstående tyckte att det var naturligt att den sjuke skulle få dö hemma och de närstående gjorde detta av kärlek. De ville känna att de gjort allt vad som kunnat göras. I Wennmans och Tishelmans studie (2002) framkom att närstående upplevde att det inte fanns några alternativ då det var nerdragningar på sjukhusplatser. Det beskrevs att det hade varit opersonligt och "kallt" att den sjuke skulle få dö på sjukhus eller någon annanstans (Exley \& Tyrer 2005). Det fanns en önskan att få fortsätta med ett så normalt familjeliv som möjligt och det fanns negativa erfarenheter utifrån vård på institution. Närstående trodde det skulle bli en positiv upplevelse då massmedia hade framställt att det var idealiskt att få dö hemma (Stajduhar \& Davies 2005). Närstående hade även känt sig pressade av hemsjukvårdspersonalen som uttryckt att hemmet var att föredra för vården av den sjuke (Millberg \& Strang 2004, Stajduhar 2003).

Beslutet att vårdas hemma togs ofta utan vetskap om hemsjukvårdens existens. Närstående tog för givet att de var ansvariga för den dagliga vården hemma och var förvånade och positivt överraskade av det professionella stöd som kunde erbjudas. Närstående förväntade sig inte att få någon hjälp från hemsjukvården för sin egen del till exempel för avlösning (Wennman \& Tishelman 2002). Patienter och närstående blev tillfrågade angående sina förväntningar på ett palliativt hemsjukvårdsteam innan patienten blev ansluten till denna vårdform och Goldschimt et al (2006) fann att det var väsentligt att personalen skulle ha specialkunskaper och erfarenhet av palliativ vård. Det var också betydelsefullt att vårdformen förbättrade säkerheten för patient och närstående. Det var även viktigt att patienten kunde erbjudas en plats på sjukhuset om ett behov uppstod. Efter patienten varit inskriven i hemsjukvården några veckor gjordes nya intervjuer där det visade sig att patienter och närstående var positiva till vårdformen. Det framkom dock att det var en brist att teamet inte var tillgängligt dygnet runt och att närstående inte kunde bli erbjudna någon form av avlösning i hemmet.

Genom att bli ansluten till ett palliativt hemsjukvårdsteam ökade livskvalitén för den sjuke och möjliggjorde den sjukes önskan att få avsluta sitt liv i det egna hemmet (Melin et al, 2007, McLaughin et al 2007). Rollison och Carlsson (2002) fann i en enkätstudie att 90 \% av de närstående var nöjda med stödet de fick från hemsjukvården och nästan alla var nöjda med vården som den sjuke fick. Majoriteten uppgav att de skulle välja samma vårdform igen om liknande situation uppstod. Generellt var de mer nöjda med det emotionella stödet än med den information som gavs från teamet.

Exley och Tyrers (2005) resultat visade att närstående ansåg att vårdarna var professionella, effektiva, stödjande och visade ett personligt engagemang. De blev som en vän till familjen då de utöver vården till den sjuke även brydde sig om resten av familjen vilket var värdefullt. Närstående erbjöds även avlösning för att få vila eller komma ut. Att närstående kände en säkerhet både för den sjuke och för sig själv genom den palliativa hemsjukvården som var tillgänglig och kompetent kunde påvisas i Millberg et al (2003) och Rollison och Carlsson (2002). Hemsjukvården upplevdes som en trygghet som kunde nås dygnet runt (Wennman \& Tishelman 2002). 
Holmberg (2006) visade den verbala och non verbala kommunikationens betydelse för tilliten i samarbetet mellan ett palliativt hemsjukvårdteam och familjen till en döende yngre man. Familjen kände stor tillit till teamet som via kommunikationen stod för kunskap, flexibilitet, kreativitet och kontinuitet. Patientansvarig sjuksköterska och läkare beskrevs som nyckelpersoner i teamet. Sjuksköterskorna sågs som en behövlig och väsentlig del av familjen utan att det kändes som ett intrång. Teamet underlättade kommunikationen mellan mamman och den döende sonen och fick mamman att förstå sonens olika reaktioner på sin sjukdom. Hon uppmärksammades också som en viktig person för honom i den dagliga vården. Sjuksköterskorna såg även till att mannens treåriga dotter fick vara delaktig i omvårdnaden på sitt sätt genom leken. Då mannen avled kände mamman sjuksköterskornas medlidande och uppskattade att de fanns till hands i hemmet. Under tystnad visade de en respektfull empati och mamman kände att sjuksköterskorna förstod att det inte fanns ord som kunde göra förlusten av sin son uthärdlig.

Wennman och Tishelman (2002) fann att närstående upplevde oro och osäkerhet i samband med patientens utskrivning från sjukhuset. Det gällde för närstående att skapa rutiner och enas med den sjuke om hur mycket hjälp som skulle tas emot från hemsjukvården. Hudson et al (2002) menade att närstående var vanligtvis dåligt förberedda på rollen som vårdgivare och att de behövde mycket mer hjälp och stöd från de professionella vårdarna än vad som erbjudits. Närstående upplevde att de fick ta stort ansvar genom till exempel bedöma den sjukes illamående och smärta och ge morfininjektioner. Hudson (2004) redovisade att drygt 25 \% av 47 intervjuade närstående uppgav bristande stöd från vårdarna i hemmet. Bristande kontinuitet av vårdarna, otillräcklig information och dåligt bemötande angavs som bristande stöd. Dessutom kände närstående sig osäkra på hur läkarna och sjuksköterskorna kommunicerade med varandra. Organisationen kändes osäker. Perrault et al (2004) fann att närstående upplevde en känsla av hjälplöshet i samband med att den sjuke försämrades och fick inte tillräckligt med stöd i vårdandet $\mathrm{i}$ hemmet.

Brobäck och Bertö (2003) visade att närstående försökte vara med då vårdarna skötte om patienten för att på det sättet få mer information och kunskap. Närstående kände sig odugliga och hjälplösa då de inte blev visade hur de skulle göra. En del närstående avstod från att aktivt fråga personalen då de tycktes vara stressade. Närstående ville bli sedda och vara en del av vårdteamet runt patienten. Men de uttryckte ofta att de kände sig utanför vårdandet och ingen frågade efter deras åsikt då personalen var fokuserad på patienten. Närstående menade att de kände sig kränkta då de kände den sjuke bäst.

Närstående saknade att den specialiserade hemsjukvården inte var tillgänglig dygnet runt (Exley \& Tyrer 2005, Goldschmidt et al, 2006). Detta fick oönskade konsekvenser som att närstående fick lära sig att ge smärtstillande injektioner (Exley \& Tyrer 2005). Även om insatser från hemsjukvården kunde erbjudas dygnet runt så var det sämre tillgänglighet på kvällar och nätter vilket gjorde att det kunde dröja innan hjälp kunde erbjudas (Millberg et al, 2003, Rollison \& Carlsson 2002). 
Millberg et al (2003) och Stajduhar (2003) fann att närstående ansåg att hemmet hade förvandlats till en sjukhusinrättning och det var svårt att ha ett normalt familjeliv då hemmet var invaderat av teknisk apparatur och personal som kom och gick. Samtidigt var närstående medvetna om att de inte hade klarat sig utan hjälpen och hjälpmedlen.

\section{Teoretisk anknytning}

För att få vägledning i uppsatsarbetet med närståendes berättelser om sina erfarenheter av ett palliativt hemsjukvårdsteam har Travelbees (1971) omvårdnadsteori varit ett stöd. Det är framförallt att omvårdnad är en mellanmänsklig process där sjuksköterskan hjälper en individ, familj eller ett samhälle att förebygga eller bemästra upplevelsen av lidande, sjukdom och vid behov även finna mening med upplevelsen som varit vägledande. Travelbee menar att varje människa är unik och det är viktigt för sjuksköterskan att ta del av patientens egen upplevda erfarenhet av sjukdom, lidande för att få förståelse för patientens situation.

Travelbee (1971) fokuserar på omvårdnadens mellanmänskliga relation som består av möten och dess erfarenheter mellan sjuksköterskan och dem som är i behov av sjuksköterskans hjälp med omvårdnaden. Inom det aktuella problemområdet är det både patient och närståendes behov av omvårdnad av vårdteamet. Den mellanmänskliga relationen är en ömsesidig process mellan parterna men det är sjuksköterskans ansvar att relationen skapas och upprätthålls. Genom den mellanmänskliga relationen uppstår en nära kontakt med förståelse mellan sjuksköterskan och patienten och då de kan dela samma upplevelse blir den betydelsefull för dem båda.

Det som är väsentligt inom problemområdet som studeras i föreliggande studie är att Travelbee (1971) betonar kommunikationens betydelse för omvårdnaden och menar att i mötet mellan personer pågår kommunikation kontinuerligt både verbalt och non verbalt. På så sätt får sjuksköterskan kunskap och lär känna patienten för att kunna tillgodose patientens behov. Det är också av betydelse för denna studie att Travelbee pekar på att det krävs stor kunskap och skicklighet för att vårda en döende patient. Sjuksköterskans egna känslor om döendet, döden, religiösa övertygelse, livsfilosofi och tidigare erfarenheter präglar omvårdnaden.

\section{Problemformulering}

Många människor vill dö i sitt eget hem enligt både svenska och internationella studier. I Sverige har det under de senaste 15 åren skett en förskjutning av dödsplatsen från sjukhus till särskilda boenden och det egna hemmet.

Utbyggnaden av avancerad hemsjukvård har ökats påtagligt sedan millennieskiftet (Socialstyrelsen 2006). Eftersom närstående tar ett stort ansvar i denna vård är det väsentligt att ta del av deras erfarenheter av ett palliativt hemsjukvårdsteam då de ofta är i en svår situation. 


\section{SYFTE}

Syftet med denna studie var att belysa närståendes erfarenheter av ett palliativt hemsjukvårdsteam.

\section{METOD}

Data består av 13 intervjuer med närstående till patienter som vårdades hemma till livets slut med hjälp av ett palliativt team. Dessa intervjuer utgör data för två olika studier med två olika författare. Föreliggande studie belyser närståendes erfarenheter av ett palliativt hemsjukvårdsteam och författaren intervjuade sju närstående. Under intervjun ställdes frågor utifrån båda studiernas syften och därmed kom data att bestå av 13 intervjuer.

\section{Kvalitativ ansats}

En kvalitativ ansats valdes som metod för att få fram beskrivningar av den närståendes erfarenheter. Intervju som datainsamlingsmetod valdes därför att då framkommer kunskap genom ett samspel mellan två personer som samtalar om ett ämne av gemensamt intresse (Kvale 1997). Under intervjun kan den närstående berätta mera på ett djupare plan och göra förtydligande med hjälp av författarens följdfrågor. Det är den närståendes upplevelser, uppfattningar och erfarenheter av en företeelse som är det intressanta för intervjun (Dahlberg 1997).

\section{Urval och procedur}

Författaren fick godkännande från verksamhetschefen att genomföra studien och hämta uppgifter från journaler. Kriterier för att ingå i studien var att deltagaren skulle ha varit maka/make eller sambo till patienten som avlidit och vårdats i hemmet till livets slut med hjälp av ett palliativt team i västra Sverige. Patientens vårdtid av teamet skulle ha varit minst 14 dagar. Deltagarna skulle vara svensktalande. Minst fyra månader och längst 12 månader från det att patienten avlidit skulle ha förflutit då de närstående kontaktades.

Av de patienter som avled hemma under mars till december år 2005 genomfördes en sökning i journalerna utifrån ovanstående kriterier. Sjutton närstående uppfyllde kriterierna. Två av de 17 närstående bedömdes av patientansvariga sjuksköterskor inte vara i så god hälsa för att genomföra en intervju och tillfrågades därför inte. En närstående ströks på grund av afasi. En närstående gick inte att nå via telefon. De sjuksköterskor som varit patientansvariga ringde upp de 13 närstående vilka uppfyllde kriterierna och de tillfrågades om att få ett informationsbrev om studien hemsänt (bilaga 1). Samtliga tretton närstående tackade ja till att få brevet. Efter en vecka kontaktades de närstående av intervjuarna och samtliga lämnade sitt samtycke till att delta i studien. Intervjuerna gjordes från mars till juni 2006.

Deltagarna bestod av åtta män och fem kvinnor. Tio närstående var ålderspensionärer och tre var yrkesarbetande. De närstående hade fått hjälp från det palliativa teamet mellan tre veckor till 18 månader. 
Från de sju intervjuer som författaren gjorde själv hade författaren tidigare via sitt arbete träffat samtliga närstående. Författaren hade varit ansvarig sjuksköterska för en av patienterna.

\section{Intervjun}

Innan intervjun påbörjades informerades de närstående att deras berättelse låg till grund för två studier, deras upplevelse av att vara anhörigvårdare samt deras erfarenhet av det palliativa teamet. De närstående påmindes om att det var frivilligt att delta, att bandspelaren kunde stängas av när de så ville, att deras identitet inte skulle röjas och att bara de som arbetade med studien skulle ha tillgång till materialet. I föreliggande studies problemområde inleddes intervjun med frågan "Kan du berätta om dina erfarenheter av det palliativa teamet”. En intervjuguide användes som mall för att stämma av med de frågor som skulle beröras. Frågor som togs upp om det inte framkom i samtalet var teamets tillgänglighet och kontinuitet, vad som kunde ha gjorts bättre från teamet samt vilket stöd närstående fick från teamet efter patienten avlidit. För övrigt formulerades frågor och författarens kommentarer under intervjuerna i syfte att utveckla intervjun som ett samtal och därmed förstå den närstående genom att förmå denne att berätta om företeelsen så utförligt som möjligt (Dahlberg 1997). Efter intervjun blev närstående tillfrågade om hur de kände sig. De blev tillfrågade om förnyad kontakt med någon från teamet önskades eller om de var i behov av annat stöd på grund av olika känslor och reaktioner som kunde ha väckts under intervjun. Inga närstående var i behov av ytterligare samtal från någon i teamet. En närstående fick hjälp från författaren att komma i kontakt med en grupp för närstående så kallad "leva vidare grupp”. Detta efterlevandestöd bestod av en grupp närstående som alla mist en familjemedlem eller god vän och gruppen skulle träffas regelbundet under sex till åtta tillfällen under ledning av en diakon.

En närstående valde att göra intervjun på författarens arbetsplats och de övriga valde att vara i hemmet. Intervjutiden varierade mellan 25 - 75 minuter. Mediantiden var 50 minuter. Materialet skrevs ut i nära anknytning till intervjuerna.

\section{Kvalitativ innehållsanalys}

I denna studie har kvalitativ innehållsanalys använts som analysmetod (Graneheim \& Lundman 2004). Innehållsanalys är ursprungligen en kvantitativ metod, men har även utvecklats i en kvalitativ riktning. Metoden används för att vetenskapligt analysera ett dokumenterat, skrivet, uttalat eller symboliskt framställt material (Eriksson 1992). Målet med innehållsanalys är att få kännedom om och få förståelse för fenomenet i studien. Eftersom innehållsanalys fokuserar på kommunikation mellan människor är den lämplig för omvårdnadsforskning (Downe-Wamboldt 1992). Skapandet av kategorier är kärnan i innehållsanalys. Innehållet i kategorierna står för det manifesta centrala tydliga innehållet. Det latenta innehållet kan analyseras fram i ett tema. Det kan dock bli någon form av tolkning även av det manifesta innehållet beroende på dess abstraktionsnivå (Graneheim \& Lundman 2004). Exempel från analysens gång är redogjord för i Tabell 1. 
- Intervjuerna numrerades 1-13 och lästes igenom flera gånger för att få en helhet.

- Meningsbärande enheter utifrån studiens syfte ströks under.

- Meningsbärande enheter kondenserades och skrevs in manuellt jämte texten.

- Varje kondenserad enhet kodades med siffror som skrevs in jämte den kondenserade enheten. Koderna numrerades för att sen lätt kunna hitta tillbaka till textens helhet.

- De numrerade koderna från alla intervjuerna skrevs ner.

- Koderna studerades sen närmare med tanke på skillnader och likheter och grupperades i ett flertal olika preliminära kategorier där koder som handlade om samma sak hamnade i samma kategori.

- Analysen rörde sig framåt och tillbaka mellan stegen, gick från delar till helheten och vice versa.

- Författaren och handledaren gick sen tillsammans igenom de preliminära kategorierna och några kategorier ändrades och slogs ihop och gavs nya namn.

- Ett övergripande tema kunde fås fram från kategorierna. Citat användes för att förtydliga kategorierna.

Tabell 1. Kvalitativ innehållsanalys. Exempel på analysens gång från meningsbärande enhet till kategori.

\begin{tabular}{|l|l|l|}
\hline Meningsbärande enhet & Kondenserad enhet & Kategori \\
\hline Vi satt vid köksbordet och & Planerade för nästa dygn, & Att dela ansvaret med \\
pratade efter de varit inne & jag tog nya tag & teamet \\
hos Bengt, planerade för & & \\
nästa dygn liksom, det & & \\
kändes väldigt skönt då & & \\
det var gjort, jag tog nya & & \\
tag. & & \\
\hline
\end{tabular}

\section{Etiska övervägande}

Enligt Etiska riktlinjer för omvårdnadsforskning i Norden publicerade av Sykepleiernes Samarbeid i Norden (2007) bygger forskningsetiska krav på de etiska principer som uttrycks i FN: s deklaration om de mänskliga rättigheterna och i Helsingforsdeklarationen. Författaren har följt de etiska principer som gäller för omvårdnadsforskning i Norden; principen om autonomi, om att göra gott, om att inte skada samt principen om rättvisa. Principen om autonomi säkerställs genom frivillighet, skydd av privatliv, informerat samtycke och kunna dra sig ur utan att ange skäl. Autonomi innefattar också att data behandlas konfidentiellt. Principen om att göra gott avser att forskningen ska vara till nytta för omvårdnaden av det som forskningen avser. Principen om att inte skada menas att forskningen inte får ha skadlig inverkan på dem som deltar och åtgärder måste vidtas för att förhindra eller minimera dess risker. Principen om rättvisa värnar om svaga grupper så dessa inte utnyttjas i forskningen. Av den anledningen skulle 
det minst ha förflutit fyra månader från det att patienterna avlidit innan intervjuerna gjordes då det var sannolikt att de närstående tidigare efter att patienten avlidit var inne i en känslomässigt svårare period. Närstående fick information om studien dels skriftligen och dels muntligen i samband med intervjun. Informerat frivilligt samtycke hämtades från de närstående. Närstående upplystes om att intervjun när som helst kunde skjutas upp till senare tillfälle eller avbrytas helt om de ville. Närstående fick information om att datamaterialet avidentifierades och att banden förvarades i låst utrymme oåtkomligt för obehöriga. Då det var möjligt att samtalen skulle väcka svåra känslor blev de närstående erbjudna förnyad kontakt med någon från teamet eller gavs råd om annat stöd. Författaren stannade kvar efter intervjun så länge som det uppfattades finnas behov av det från den närstående.

Författaren har arbetat många år med palliativ omvårdnad och har på så sätt kunskap om ämnet som studerades. Samtliga resultat utifrån studiens syfte är redovisade. Studien har bedömts av en forskningsetikgrupp vid Institutionen för vårdvetenskap och hälsa, Göteborgs Universitet.

\section{RESULTAT}

Resultatet består av ett övergripande tema och sex kategorier utifrån analysen av närståendes berättelser om erfarenheter av ett palliativt hemsjukvårdsteam.

Kategorierna beskriver olika aspekter av erfarenheterna som närstående berättade om. Alla kategorier är lika viktiga.

I resultatpresentationen benämns intervjupersonerna som närstående och personen som är sjuk benämns som patient. Personerna i det palliativa teamet benämns som vårdare oavsett profession om inte yrkeskategorin är specificerad av närstående under intervjun. Det palliativa teamet benämns genomgående som teamet i den löpande texten. Namn i citat är fingerade. Citaten förtydligar kategorierna. I citaten har beteckningen // använts för att utesluta ett stycke som inte har ett väsentligt innehåll för kategorin. I citaten innebär tre punkter (... ) att det är en tystnad. Citaten är markerade med en siffra som anger olika deltagare.

\section{Övergripande tema}

Det övergripande temat tacksamma för tryggheten men upplevde utsatthet omfattar samtliga kategorier. Närstående var tacksamma för tryggheten som det palliativa teamet möjliggjorde som innebar att de förlitade sig på vårdarna i teamet och att de blev inbjudna och fick stöd i vårdandet. Detta gjorde att de kunde dela ansvaret för vården med teamet. Men de närstående upplevde också utsatthet som innebar att de inte var införstådda med vården och att de upplevde påfrestningar. Efter patienten avlidit uttrycktes ytterligare behov av stöd från teamet. (Tabell 2). 
Tabell 2. Resultatets övergripande tema och kategorier

\begin{tabular}{|l|l|}
\hline \multicolumn{2}{|c|}{ Tacksamma för tryggheten men upplevde utsatthet } \\
\hline Att förlita sig på vårdarna i teamet & Att inte vara införstådd \\
\hline Att bli inbjuden och få stöd i vårdandet & Att uppleva påfrestningar \\
\hline Att dela ansvaret med teamet & Att få stöd efter vårdtiden \\
\hline
\end{tabular}

\section{Att förlita sig på vårdarna i teamet}

Närstående förlitade sig på vårdarna i teamet. De upplevde att vårdarna var samspelta och det fanns en jämn och hög yrkeskicklighet. De var väldigt nöjda med vården som gavs genom att de fick hjälp från teamet för att kunna tillgodose patientens behov. Olika hjälpmedel som underlättade för patienten och omvårdnaden var snabbt på plats. Det framkom i närståendes berättelser att det fanns god kommunikation och rapportering mellan vårdarna som kom patient och närstående tillgodo.

"Jag tycker att det var väldigt, fanns väldigt mycket mänsklig vård eller närhet från teamets sida, de mötte alla de behov som var"...(4)

Närstående berättade att de trodde att det skulle komma ännu fler olika vårdare från teamet än de som kom. Det beskrevs att det var många personer men att flera återkom regelbundet så det blev ändå en viss kontinuitet. Ingen upplevde det negativt med besök från många olika vårdare från teamet, dock kändes det skönt med ett bekant ansikte. Vårdarna upplevdes olika i sina personligheter men det var på ett positivt sätt. Alla var duktiga och de beskrevs som om de vore handplockade. Sjuksköterskorna beskrevs som professionella och var oerhört lika i sin yrkesutövning. Det fanns stor tillit till dem och vården som gavs. Närstående framhöll också att det var bra med två vårdare som hjälptes åt då de kom på natten. De kunde dela upp sina arbetsuppgifter mellan sig på ett bra sätt och det var väldigt smidigt.

”Jag har lättast att se nackdelar kanske och att man då kan få en sån samling människor som man inte kan hitta något negativt, det tycker jag var förvånande.” (8)

Närstående såg att vårdarna i teamet hade olika roller och mest kontakt hade de med ansvarig sjuksköterska och läkare. Den patientansvariga sjuksköterskan i teamet hade överlag en betydande roll för patienten och närstående och med henne/honom diskuterades viktiga frågor. Mellan dem skapades en fin kontakt och det fanns tid för förtroendefulla samtal som uppskattades. Sjuksköterskan beskrevs också som en fixare, kunde hjälpa till med det mesta, ställde upp jämt och inget var omöjligt. Närstående berättade att den patientansvariga sjuksköterskan hade regelbunden kontakt med dem och att läkaren kom efter behov. Efterhand som patienten blev sämre kunde det bli tätare och längre gemensamma besök vilket var behövligt och uppskattades av de närstående. Ibland var det skönt för den närstående att medan patienten fick omvårdnad av sjuksköterskan kunde läkaren prata mer enskilt med den närstående. Det beskrevs 
att patienten fick effektiv medicinering sista tiden i livet som underlättade för patienten. Närstående berättade att det blev en lugn och fridfull avslutning.

...”Något som också kändes bra var att den sjuksköterska som var ansvarig kom väldigt ofta. Det gjorde att jag kände en inre styrka. Då visste jag att det gick bra med de andra som dök upp.” (11)

\section{Att bli inbjuden och få stöd i vårdandet}

Samtliga närstående berättade upprepade gånger under intervjuerna att de kände stort stöd från teamet och var nöjda och tacksamma med dess insatser. De hade inte förväntat sig att få så mycket hjälp som de fick och var förvånade över att det fungerade så bra som det gjorde. Det framkom att det första mötet med teamet var betydelsefullt. Kontakten upplevdes positiv, det fanns gott om tid och det kändes bra för både patienten och närstående. Närstående berättade att det underlättade då vårdarna kunde sköta sjukvården hemma, de slapp åka iväg med patienten och passa olika tider. De förstod också efterhand att de skulle få den hjälp de behövde.

"Jag hade inte i min vildaste fantasi kunnat tänka mig att det var så pass bra// jag hade inte ansvaret för det, ni tog ansvaret av det hela, han fick precis vad han sa eller vad ni ansåg han skulle göra, jag kunde ju ringa när som helst så kom ni när det behövdes.” (8)

Närstående berättade att det kändes tryggt med att alltid kunna nå vårdarna dygnet runt. Det fanns en informationspärm hemma med aktuella namn och telefonnummer. Bara vetskapen om att alltid kunna nå en sjuksköterska som kände till patientens situation gjorde att närstående upplevde att de fick stöd och kände sig därmed lugnare. Genom ett telefonsamtal kunde närstående få goda råd och svar på sina frågor och ibland kunde detta räcka för att närstående skulle känna sig bättre till mods. Vårdarna kom alltid hem då det upplevdes ett behov av stöd och hjälp. Det var inga längre väntetider och närstående upplevde att patienten fick hjälp snabbt oavsett vilken tidpunkt de larmade. Dock beskrev närstående att det kunde vara längre väntetider på kvällar och nätter men hade förståelse för detta. Närstående berättade att de fick den hjälp som behövdes och tyckte att allt fungerade bra. Att läkaren kunde komma då det behövdes var också betydelsefullt stöd. Det berättades att det fanns gott om tid i samband med vården till patienten och det var ingen som var stressad under besöken. Närstående uppskattade att vårdarna ringde om de inte kunde komma på de överenskomna tiderna. De förstod att det kunde bli förseningar ibland och då var det skönt att få reda på det i tid. Även andra familjemedlemmar hade till de intervjuade närstående uttryckt att stödet och vården från teamet var fantastisk. Närstående berättade att de inte hade klarat sig utan teamet. Utan denna hjälp hade inte patienten kunnat vårdas hemma till livets slut.

"Jag tyckte att det var jättegott att ha er. Jag ringde er inte så många gånger men när jag gjorde det så behövde jag er. Då var det medicinerna och jag behövde prata och gråta lite.” (10) 
Närstående berättade om bra bemötande och förståelse från teamet. Det beskrevs att vårdarna var vänliga och trevliga. Stämningen var god och det fanns utrymme för skoj och skämt. Närstående berättade att vårdarna uppmärksammade deras situation också. En klapp på axeln eller en betydelsefull blick gjorde att närstående kände sig sedda i sin situation. Närstående blev tillfrågade om hur de mådde och det kändes skönt med teamets omtanke vilket gav stöd.

Det framkom från närstående att det hade varit bra att träffa andra närstående som var i liknande situation under vårdtiden. Men det uttrycktes också att närstående inte hade velat eller orkat med detta. De menade att de hade familjemedlemmar eller vänner att prata med. De ville klara sig själva och menade att de hade hoppet kvar även om de innerst inne visste att tiden var utmätt.

Närstående berättade att det var skönt att det inte uttrycktes i ord att livet nästan var slut för patienten. Det framkom ändå i mötet med vårdarna och närstående såg själva försämringen och förstod att det inte var så lång tid kvar. Det uppskattades också att vårdarna inte gav besked om hur lång tid det var kvar.

"Sista gången doktorn var här såg jag på honom att Allan inte hade så långt kvar så han behövde inget säga, det såg jag på doktorn och jag tror att det var svårt för er att säga att nu är det inte så långt

kvar. Allan frågade själv att nu har jag väl inte så långt

kvar och då höll han ju Allan i handen.” (10)

Närstående berättade att de fick en skriftlig broschyr av teamet som beskrev hur det kunde vara den sista tiden i livet. Broschyren förtydligade och kompletterade den muntliga informationen från vårdarna och uppskattades av de närstående. Den var även viktig för andra familjemedlemmar som inte hade samma kontakt med vårdarna som de intervjuade närstående hade.

Närstående beskrev att de aldrig hade fått så mycket stöd och hjälp om patienten hade varit inlagd på sjukhuset. Hemma fick de täta besök av de vårdare från teamet som de behövde hjälp från. Det fanns även tid för stödjande samtal som de upplevde att de inte skulle få på ett sjukhus.

”Jag känner stor tacksamhet mot alla som var här. Jag rekommenderar det till alla jag pratar med. Skulle jag gå bort själv skulle jag vilja ha det på det viset. När man såg hur fint det kan vara jämfört med vad jag sett på sjukhus. Allt stämde." (7)

\section{Att dela ansvaret med teamet}

Närstående berättade att det kändes naturligt att hjälpa patienten i omvårdnaden och dela ansvaret tillsammans med teamet. Det som de klarade av, ville de ta ansvar för så långt de kunde. De hjälpte patienten med att ge mediciner, kontrollera blodsocker, sådant som patienten själv tidigare hade skött. Närstående beskrev att de försökte underlätta för teamet genom att plocka fram material som behövdes för att till exempel blanda och sätta dropp och för att göra 
såromläggningar. Närstående lärde sig att kontrollera dropphastigheten och lägga om enklare sår och fick beröm från teamet. Närstående beskrev att de kände sig delaktiga i vården och ville vara med hela tiden i vad som hände. De behövde finnas till hands hemma och vara en förmedlande länk mellan patient och vårdare. En kontaktbok mellan närstående och vårdarna upprättades av närstående som arbetade. Genom denna bok kände närstående sig delaktig i vården och visste vad som hade hänt då vårdarna skrev hur det var då de besökte patienten.

”...droppet på natten, det läckte vid förgreningen, då visste jag inte hur jag skulle göra för jag känner inte till det, men då var dom ju här på 20 minuter, sen visste jag hur man gjorde och sen såg jag till att det inte gjorde så och det är så mycket man kan sköta själv...” (3)

Närstående ville veta hur situationen var för patienten och de var nöjda med informationen från teamet som underlättades deras delaktighet. Närstående i sin tur delgav teamet sin version om hur de upplevde patientens tillstånd. Närstående frågade själv vårdarna om det var något de inte förstod och ansåg att de fick svar på det som gick att besvara. Det beskrevs att i livets slutskede förekom en daglig rond och efteråt samlades närstående, läkaren och sjuksköterskan i ett annat rum för att prata om hur de såg på tillståndet och tillsammans gjordes en fortsatt planering för vården.

Ibland kändes ansvaret tungt för den närstående. Det skulle kontrolleras effekter av medicinering och rapporteras till teamet. Det var också betungande att försöka få i patienten vätska och hålla kontroll på urinmängder. Det var även svårt att bedöma hur svår smärta patienten hade och utifrån detta försöka övertala patienten till att ta olika mediciner.

”...ja, dom ville att jag skulle kolla det och jag var ju sjuksköterska, visste hur viktigt det var, och det att jag var sjuksköterska var egentligen en nackdel för då kände jag sådant ansvar också...som man gör som sjuksköterska (gråter).” (2)

Närstående berättade att de ansvarade för att ta kontakt med teamet då de märkte att patienten var i behov av ytterligare hjälp utöver de inplanerade besöken. Det kunde vara att patienten behövde smärtlindring, droppet krånglade, förstoppning eller kateterkrångel. Ibland behövdes bara råd från vårdarna för att närstående sedan skulle klara av situationen.

Närstående berättade att de inte fick den nattsömn som egentligen behövdes. Det hände att patienten var orolig på natten och då var det svårt för närstående att kunna sova. Patienten hade dropp på nätterna och det hände flera gånger att droppet krånglade och teamet fick kontaktas. Trots oron på natten ville närstående klara nätterna själva och hade inte velat ha avlösning för att sova. De ville vara nära, vara med hela tiden och hade inte kunnat gå ifrån för att lägga sig i ett annat rum. Patienten hade uttryckt till närstående att inte vilja ha någon vårdare på natten. 
” Ja...man sover ungefär som man sover då man har småbarn, man ligger, man sover lite på ytan, man vaknar för minsta lilla ljud." (8)

\section{Att inte vara införstådd}

Närstående berättade att de inte förstod hur dålig patienten var. Närstående fortsatte att arbeta då det antytts att patienten kunde leva länge med sin sjukdom. Olika åtgärder från teamets sida gjorde att närstående trodde att patienten skulle leva mycket längre än vad som var fallet. Till exempel fick patienten hem olika hjälpmedel och då trodde närstående att detta skulle användas under en längre tid.

”Sen när vi fick hjälpmedel då trodde jag också att det också var lång tid kvar, vi fick pallen till badrummet, han skulle duscha, han använde den pallen en gång, den kom så sent in, samma var det med rullstolen.” (1)

Närstående beskrev att patienten fick symtom som trötthet som de inte satte i samband med att patienten var på väg att försämras. Detta tolkade närstående som en övergående trötthet som utlösts av olika aktiviteter. Först sista veckan förstod närstående att livet inte skulle fortgå så länge till då infektioner som tidigare behandlats nu inte längre skulle åtgärdas med antibiotika.

” Jag kanske tror att ni förstod mer än jag förstod det man kände att dom skulle säga att det är inte så långt kvar, att man kanske ännu tidigare skulle ha sagt det för ni som har sett säkert cancerpatienter ofta vet kanske på ett annat sätt hur nära...” (1)

Det framkom att om närstående hade förstått att det inte var så lång tid kvar för patienten hade de inte försökt övertala patienten att dricka och äta så mycket. De trodde att det var viktigt med dryck och mat och upplevde att de hade tjatat på patienten.

Närstående visste inte vad som skulle hända med patienten den allra sista tiden i livet och hade inte fått information förrän det var uppenbart att livet snart var slut. Närstående hade heller inte själv ställt frågan utan tänkt att vårdarna kanske ansåg att det skulle förstås ändå. Närstående berättade att den skriftliga informationen om döendet borde lämnas ut tidigare än vad som gjordes och informationen borde även följas upp från vårdarna.

\section{Att uppleva påfrestningar}

Det framkom att närstående upplevde påfrestningar i olika situationer med teamet. Trots att närstående visste att patienten hade en begränsad tid kvar att leva så blev det ändå som en chock då teamet presenterades som ett palliativt team. Det blev på ett sätt bekräftat att livet gick in i den sista fasen.

Närstående upplevde att det var otryggt då vårdarna kom senare än de överenskomna tiderna. Patienten kunde vara ensam då närstående arbetade och 
det blev en otäck känsla och rädsla hos närstående om inte tiderna hölls.

Närstående berättade att det första mötet med teamet blev fyra timmar försenat då vårdarna hade haft mycket att göra och dessutom haft svårt att hitta i mörkret. Det kändes osäkert och misstänksamt då detta var första kontakten och organisationen kändes sårbar. Det kändes en oro för om det skulle bli så sent varje kväll.

Närstående berättade om lång väntan för att patienten skulle få smärtlindring för det var skifte mellan kvälls och nattpass.

Närstående upplevde otillräckligt stöd från teamet på natten. Patienten hade svår oro och nätterna kändes tunga då inte medicineringen hjälpte. Närstående uttryckte att det är viktigt att kunna få avlösning ett par nätter för att klara av att vara påpasslig och omtänksam mot den som är sjuk. Teamet kunde inte erbjuda nattvak förrän sista natten och nätterna beskrevs som hemska med följd att dagarna blev svåra att orka med. Närstående upplevde det som tjänstgöring dygnet runt. Samma närstående hade funderat på hospice som alternativ vårdform lite längre fram när patienten förväntades bli sämre. Men patienten hade hastigt blivit försämrad och närstående hade inte förstått att försämringen skulle kunna gå så snabbt och förhindra patienten få avsluta sitt liv på hospice. Från teamet hade det framkommit att den som är sjuk bör vara ett tag på hospice för att tillgodogöra sig den speciella hospicefilosofin.

Det framkom att vårdarna inte kunde sköta den tekniska apparatur som fanns vilket ledde till att patienten inte blev smärtlindrad. Detta skapade en osäkerhet hos patient och närstående, samtidigt som de kände viss oro för om detta skulle upprepas igen.

Närstående upplevde att vårdarna uppmanade patienten att äta och dricka och ta sin medicin trots stora svårigheter och allmän försämring. Samtidigt som närstående förstod att detta var nödvändigt på grund av diabetes var det ändå betungande för både patient och närstående.

” När ni såg vart det lutade så skulle ni kanske avslutat medicineringen lite snabbare. Men det får ni ju inte göra.

Han gjorde ju det sedan. Plocka bort medicinerna successivt. Och jag ska inte heller säga att han skulle gjort det tidigare. Man kan ju inte säga så men... man kan inte sätta sig över allting och avsluta människors liv. Hon hade det ju tungt på slutet." (13)

Vårdare försökte påverka situationen så att patienten skulle flytta till annat boende då de såg att det var tungt och slitsamt för närstående. Vårdarna såg inte närståendes önskan om att vårda patienten hemma till livets slut. Detta blev en påfrestning för närstående som inte fick det rätta stödet från vårdarna.

Närstående upplevde påfrestning genom att de kände sig kränkta då vårdare formulerat sig olämpligt i mötet med patienten. Patienten blev påmind om att livet snart var slut vilket närstående upplevde som inkräktning av integriteten. Vårdare föreslog åtgärder som patienten tidigare uttryckt inte vilja vara med om för att upprätthålla livet. Närstående fick skuldkänslor då tanken väcktes igen och menade att de kanske skulle ha påverkat patienten att acceptera föreslagna 
åtgärder för att leva ytterligare ett tag. Det framkom ytterligare skuldkänslor och svek då närstående hade fått förfrågan om att vara med och omhänderta den avlidna patienten. Närstående ville inte detta och det kändes påfrestande.

Närstående ville inte heller att den avlidna skulle vara kvar i bostaden över natten till nästa dag som uppfattades som brukligt då ansvarig läkare skulle komma.

Närstående kände samtidigt ett svek mot patienten då inte teamets rutiner följdes.

” ...nej en sådan kommentar tycker jag att man ska

överlåta till anhöriga, på deras initiativ ska den tanken

komma, får jag vara med och klä min fru eller mitt barn

eller så, men när det kommer från personalen från teamet, så blir det åter så att andra gör det och vi gör det inte, räds för kroppen och så får man lite skuld, dåligt samvete...” (4)

\section{Att få stöd efter vårdtiden}

Närstående var tacksamma för uppföljningen från teamet efter patienten avlidit. De tyckte att det var fantastiskt att teamet hade tid för dem efter patienten avlidit då detta var ett värdefullt stöd. Det uppskattades att ansvarig sjuksköterska och läkare kom hem efter patienten avlidit. Tillsammans hade de pratat igenom hur det var under vårdtiden och det kändes bra för de närstående. Sjuksköterskan hade även ringt ett par gånger och närstående hade fått ett kort från teamet vilket uppskattades. Men det uttrycktes också att närstående hade velat ha mer kontakt och uppföljning än vad som erbjöds från teamet då patienten avlidit. Vårdtiden i hemmet var många gånger intensiv med täta besök från vårdarna. Sen blev det en väldig tomhet och tystnad då teamet drog sig tillbaka. Närstående berättade att patient, närstående och vårdare lärde känna varandra under vårdtiden och det hade varit skönt med några besök efteråt för att prata om hur det kändes. Det framkom också att efter vårdtiden fanns det en del obesvarade frågor som önskades svar på.

"Det hade kanske varit bra med lite mer än den uppföljningen som gavs// Jag tror det vore väldigt bra, för när det har gått ett par veckor har man ju sina frågor som sedan smälter bort och försvinner. Jag tror att det skulle vara bra för dem som vill. Jag hade nog velat det.” (11)

Flera närstående hade fått information om "leva vidare grupper” men bara någon enstaka hade deltagit i en sådan grupp. De menade att de hade ett socialt nätverk redan som räckte till och var inte i behov av de rekommenderade grupperna. Närstående berättade att de hade velat vara med i "leva vidare grupper" som inte ordnades via kyrkan. Men de visste inte då att detta fanns. Det sågs som en fördel om teamet arrangerade dessa grupper som då kunde ses som en naturlig fortsättning efter vårdandet. Det uttrycktes att det hade varit bra att få både muntlig och skriftlig information om "leva vidare grupper" ca 14 dagar efter begravningen då det blev så ensamt och tyst. Närstående önskade också en enkel skriftlig information om sorgearbetet i samband med patienten avled och menade att inte alla orkar söka efter information själva. 


\section{DISKUSSION}

\section{Metoddiskussion}

Syftet med denna studie var att få fram närståendes erfarenheter av ett palliativt hemsjukvårdsteam. Genom att en kvalitativ ansats valdes i form av intervjuer framkom kunskap genom samspelet mellan författare och närstående (Kvale 1997). Genom intervjun kunde följfrågor ställas för att göra förtydliganden utifrån vad närstående berättade (Dahlberg 1997). En kvalitativ innehållsanalys (Graneheim \& Lundeman 2004) användes för att analysera de utskrivna bandinspelade intervjuerna. Metoden ansågs och visade sig vara lämplig då innehållsanalys fokuserar på kommunikation mellan människor (DowneWamboldt 1992).

Av de 17 närstående som uppfyllde kriterierna för studien exkluderades fyra närstående. Två bedömdes av de patientansvariga sjuksköterskorna att inte vara i tillräckligt god hälsa för att genomföra en intervju, en närstående hade afasi och den fjärde gick inte att nå via telefon. Författaren ansåg det var väsentligt att inkludera alla övriga och inte välja eller få utvalt närstående med troligen goda erfarenheter från teamet. Allas erfarenheter skulle speglas i resultatet vilket bidrar till trovärdigt resultat. Ingen av de tillfrågade närstående tackade nej till att delta vilket skulle kunna bero på att det kändes betydelsefullt att dela med sig av sina erfarenheter. Det skulle också kunna vara så att de var tacksamma för vården och hjälpen de fått och nu hade en chans att ge något tillbaka. Vårdtiden skulle vara minst 14 dagar för att närstående skulle kunna återge en omfattande erfarenhet från teamet.

Författaren i föreliggande studie gjorde själv sju intervjuer och de övriga sex genomfördes av annan person som också arbetade i teamet. Samtliga närstående som intervjuades hade träffat författarna en eller flera gånger och det kan ha påverkat resultatet i positiv riktning. Men närstående påpekade att de inte längre hade någon relation till teamet och kunde därför uppriktigt berätta hur de upplevde sina erfarenheter från teamet. Att intervjupersonerna var kända sågs som en fördel för de närstående som menade att det inte var säkert att de hade ställt upp om författaren hade varit en obekant person. Närstående verkade känna sig trygga och avspända i relationen till författaren under intervjun. Närstående berättade att det kändes skönt att få delge sin berättelse till någon som kände till deras situation även om det stundtals var ledsamt under intervjun. Det var flera närstående som reflekterade över vad de varit med om under intervjuns gång och som kan ha bidragit till förståelse för vad de gått igenom. Att som författare tidigare ha träffat de intervjuade närstående gjorde att det kändes avslappnat under intervjun.

Då frågor ställdes utifrån två studiers olika syften kan det ha bidragit till att intervjuerna blev längre, men samtidigt blev det en helhet eftersom de närstående fick berätta om sina upplevelser att vara närstående och sina erfarenheter från teamet. Att intervjuerna var olika långa kan bero på att det inte var samma intervjuare och att deltagarnas förmåga att berätta varierade. Samma frågeområden men med olika djup beroende på närståendes förmåga eller vilja att berätta täcktes i intervjuerna. Graneheim och Lundman (2004) menar att för 
trovärdigheten är det viktigt att alla deltagare får samma frågor, samtidigt som intervjuer är en utvecklande process och det är naturligt att intervjun kan leda till nya frågor.

Genom att noggrant beskriva hela tillvägagångssättet i metoden och analysen ökas trovärdigheten. Trovärdigheten av resultaten beror också på hur pass kategorierna täcker data så att ingen relevant information har blivit oavsiktligt eller systematiskt exkluderat. Genom användning av citat ökas också trovärdigheten (Graneheim \& Lundman 2004). Författaren hade hela tiden syftet i fokus då meningsbärande enheter utifrån syftet plockades ut från intervjutexten.

Författaren har strävat efter att noggrant beskriva metoden med dess analys, och handledaren har tillsammans med författaren studerat koder och kategorier samt tema. Överförbarhet handlar om i vilken omfattning resultatet kan överföras till liknande grupper, dock blir det läsaren som får avgöra detta (Graneheim \& Lundman 2004).

\section{Resultatdiskussion}

Genom att undersöka 13 närståendes erfarenheter av ett palliativt hemsjukvårdsteam har kategorierna att förlita sig på vårdarna i teamet, att bli inbjuden och få stöd i vårdandet, att dela ansvaret med teamet, att inte var införstådd, att uppleva påfrestningar samt att få stöd efter vårdtiden identifierats. Att närstående var tacksamma för tryggheten men upplevde utsatthet lyftes fram som ett övergripande tema.

Närstående förlitade sig på vårdarna i teamet

Resultatet visar att närstående förlitade sig på vårdarna i teamet. Inom teamet fanns hög kompetens och god kommunikation som gjorde att patientens omvårdnadsbehov kunde tillgodoses. Vårdarna i teamet hade alla flerårig erfarenhet inom palliativ vård och Travelbee (1971) menar att det krävs stor kunskap och skicklighet för att vårda en döende patient. Tidigare erfarenheter och egna känslor om döendet och döden präglar omvårdnaden. Andra studier visade också att närstående kände tillit till vårdarna som beskrevs som professionella och hade goda kunskaper (Exley \& Tyrer 2005, Holmberg 2006). Närstående uppskattade att då patienten blev sämre gjorde sjuksköterskan och läkaren tätare och gemensamma hembesök. Det fanns ett behov från närstående att ibland få prata enskilt med läkaren utan att patienten var närvarande och det kändes bra att patienten då var upptagen av sjuksköterskan. Travelbee (1971) fokuserar på omvårdnadens mellanmänskliga relation som är en ömsesidig process mellan sjuksköterskan och de som är i behov av sjuksköterskans tjänster. Travelbee betonar att det är sjuksköterskans ansvar att relationen skapas och upprätthålls och i resultatet framkom att den patientansvariga sjuksköterskan hade en viktig roll i teamet och det skapades betydelsefulla relationer mellan patient, närstående och sjuksköterskan. Även Holmberg (2006) visade på den ansvariga sjuksköterskans betydelse för familjen.

Ingen av de intervjuade närstående tyckte det var negativt att det var flera olika vårdare som kom under vårdtiden i hemmet. Detta skulle kunna förklaras med den tillit som de upplevde till teamet som var uppdaterat på patientens situation och behövde inte fråga närstående vad som skulle göras. Även att alla sjuksköterskor 
utförde sitt arbete på liknande sätt kan också bidra till att det gick bra med flera olika sjuksköterskor. I Hudsons (2004) studie däremot framkom bristande kontinuitet bland vårdarna som negativt och närstående menade att organisationen kändes osäker då det brast i kommunikationen mellan sjuksköterskorna och läkarna.

\section{Närstående var tacksamma för tryggheten}

Resultatet visar att närstående kände sig trygga med vårdformen genom att de blev inbjudna och fick stöd i vårdandet. De hade inte förväntat sig att få så mycket stöd och hjälp som de fick vilket också påvisades av Wennman och Tishelman (2002). I föreliggande studies resultat framkom att de närstående kände sig förstådda av vårdarna eftersom de kunde dela samma upplevelse. Närstående blev sedda och fick plats i vårdandet. Travelbee (1971) menar att genom den mellanmänskliga relationen uppstår en nära kontakt med förståelse som blir betydelsefull då de inblandade delar samma upplevelse.

Trots att patienten var mycket sjuk fanns det ändå utrymme för vardagliga samtal och skämt mellan vårdare, patient och närstående vilket var uppskattat. Närstående jämförde hemsjukvården med om patienten varit inneliggande på sjukhus och menade att de inte hade fått samma stöd där som de fick från teamet. Likt resultatet från Rollison och Carlsson (2002) framkom att närstående skulle välja samma vårdform igen om liknande situation uppstod.

Teamet var tillgängligt dygnet runt vilket upplevdes av närstående som en trygghet för både patient och de själva. För att kunna ge god palliativ vård i hemmet är enligt Beck-Friis och Österberg (2005) en förutsättning att den kvalificerade vården ska kunna ges dygnet runt. Det fanns en förståelse från de närstående att det kunde ta längre tid för att få hem en sjuksköterska på kvällen och natten.

Det var viktigt med både muntlig och skriftlig information om döendet och i mötet med vårdarna förstod närstående när det inte var så lång tid kvar av patientens liv utan att det nämndes i ord. Travelbee (1971) menar att kommunikation pågår kontinuerligt verbalt och non verbalt i mötet mellan sjuksköterska och patient och i denna studie gäller det även mellan vårdare och närstående. Holmberg (2006) visade också den tysta kommunikationens betydelse då en mamma som mist sin son fick stöd och kände en respektfull empati från sjuksköterskorna som tysta fanns till hands i hemmet.

\section{Närståendes erfarenheter av att dela ansvaret med teamet}

Närstående kände att de delade ansvaret för patienten med teamet genom att hjälpa till med det de kunde och vårdarna uppmuntrade delaktigheten. Det som patienten tidigare hade skött själv försökte de ta över. Närstående försökte även underlätta för teamet genom att plocka fram vad som behövdes vid vårdandet. Genom att vara delaktiga visste de hela tiden vad som hände och det framkom att informationen var tillräcklig annars frågade de själva. Även i livets slutskede framkom att närstående tillsammans med sjuksköterskan och läkaren var delaktiga i planeringen för den fortsatta vården av patienten. Holmberg (2006) visade också hur det palliativa teamet fick familjen att känna sig välinformerad och delaktig i vården till en döende ung man och sjuksköterskorna såg familjen ur 
ett helhetsperspektiv. Andershed och Ternestedt (1998) menar att närstående känner en meningsfull delaktighet, som benämns att vara i ljuset, vilket innebär att känna sig välinformerad av vårdarna och att relationen mellan dem baseras på tillit och förtroende. Motsatsen benämns som delaktighet i mörkret då närstående är dåligt informerade, känner sig inte sedda och får inte något stöd i vårdandet som kunde påvisas i Brobäck och Bertö (2003) där närstående kände sig utanför vårdandet och kände sig odugliga då de inte visste hur de skulle göra. Resultatet från föreliggande studie visade också att några närstående inte var införstådda med hur dålig patienten var och de trodde det var längre tid kvar av livet. De tolkade olika åtgärder från teamet som att patienten inte var döende vilket också framkom i Millberg och Strangs (2004) resultat. I författarens studie menade närstående att teamet utifrån sin erfarenhet skulle ha berättat och försökt få dem att förstå att patienten skulle avlida inom kort tid. Informationen från teamet var inte tillfredställande och närstående visste inte heller hur det kunde bli då patienten skulle dö. Närstående önskade bli tidigare informerade om själva döendet och att den skriftliga informationen skulle följas upp från teamet. Rollison och Carlsson (2002) visade också att närstående ville ha muntlig och skriftlig information om själva döendet.

I resultatet framkom att patienterna hade olika hjälpmedel som underlättade i vårdandet. Ingen av de intervjuade närstående kommenterade detta som något negativt. Däremot visade Millberg et al (2003) och Stajduhar (2003) att närstående upplevde det som om hemmet hade förvandlats till ett sjukhus och det var svårt att ha ett normalt familjeliv då personal kom och gick. Detta kunde heller inte påvisas i föreliggande studie.

\section{Närstående upplevde utsatthet}

Det var inte bara positivt att ta så mycket ansvar som närstående gjorde. Ibland tog närstående ett för tungt sjukvårdande ansvar och istället för att vara maka eller make blev närstående sjukvårdspersonal och skulle till exempel göra olika bedömningar och rapportera till teamet. Även andra studier visade att närstående fick ta för stort ansvar och exempelvis ge smärtstillande injektioner (Hudson et al 2002, Exley \& Tyrer 2005). På natten delades också ansvaret med teamet som kontaktades då närståendes egen insats inte räckte till. Trots detta skulle närstående avböjt att få avlösning i hemmet om de hade fått erbjudande. De ville vara nära och inte sova i annat rum. Men det framkom också att närstående hade uttryckt önskemål om nattvak och stödet från teamet kändes otillräckligt då inte detta kunde uppfyllas. Närstående fick inte tillräckligt med sömn på grund av patientens oro och menade att det blev som ett arbete dygnet runt vilket inverkade negativt på patienten. Även resultatet från Goldschimt et al (2006) visade att närstående upplevde det som brist att inte kunna bli erbjuden avlösning i hemmet medan närstående i Wennman och Tishelman (2002) studie inte hade förväntat sig att få egen avlösning.

Närstående upplevde påfrestningar i flera olika situationer med teamet. När teamet presenterades som ett palliativt team symboliserades detta med att döden var i antågande vilket också Millberg och Strang (2004) påvisade. I föreliggande studie framkom att närstående kände sig otrygga då de uppgjorda tiderna med teamet inte hölls. Teamet var sårbart i skiftet mellan kvälls och nattpersonal vilket ibland gjorde att patienten fick vänta för att få smärtlindring. I andra studier 
(Millberg et al, 2003, Rollison \& Carlsson 2002) framkom också att hjälpen kunde dröja på kvällar och nätter på grund av sämre tillgänglighet. I föreliggande studies resultat påvisades att den tekniska apparaturen inte behärskades av alla vårdare och som ledde till att patienten inte blev smärtlindrad. Det var också betungande för närstående att trots att patienten var så dålig blev uppmuntrad av vårdare till att fortsätta med tabletter och mat.

Det framkom att närstående kände sig kränkta och även fick skuldkänslor i mötet med vårdarna. Om patienten tackat ja till föreslagna åtgärder som patienten tidigare uttryckt vilja slippa skulle livet kunna fortgå ett tag till och det framkallade skuldkänslor hos närstående. Samma närstående berättade om svek som kändes mot patienten då teamets rutiner inte följdes i samband med att patienten avled. Brobäck och Bertö (2003) visade att närstående kände sig kränkta då de inte blev tillfrågade om sina åsikter i vårdandet och menade att de kände ju patienten bäst och visste vad som var bäst för den sjuke.

Närstående hade ytterligare behov av stöd

Närstående hade olika behov av stöd och kontakt efter vårdtiden från teamet då patienten avlidit. Alla närstående hade haft någon form av kontakt från teamet och flera var nöjda med uppföljningen från teamet. Men det stöd som gavs var inte tillräckligt för alla. Det fanns frågor kvar från närstående som förblev obesvarade. Närstående menade också att de fick en god relation till vårdare i teamet under vårdtiden. De beskrev en tomhet och tystnad då patienten avlidit och dessutom upphörde besöken från teamet. Närstående skulle vilja ha ytterligare hembesök och få prata om sin situation med vårdare som kände dem väl. Enligt WHO (2002) så är en av hörnstenarna i den palliativa vården just att stödja närstående även efter vårdtiden. Andra resultat visade också att närstående tyckte att stödet var otillräckligt efter patienten avlidit (Rollison \& Carlsson 2002, McLaughin et al, 2007). Resultatet från föreliggande studie visade att närstående önskade få en skriftlig information om råd efter patienten avlidit för att underlätta sorgearbetet. Teamet stod för trygghet och det sågs som en naturlig fortsättning att det var just teamet som skulle hålla i "leva vidare grupper”.

\section{Reflektioner}

Resultatet i denna studie visade att närstående generellt var mycket nöjda och kände sig trygga med det stöd som palliativa hemsjukvårdsteamet gav dem och även med omvårdnaden till patienten vilket är betydelsefullt att veta för teamet. Men det är också av betydelse för teamet att veta att i vissa situationer räckte inte teamet till och närstående upplevde olika slag av påfrestningar och att inte stödet var tillräckligt. Trots den uttalade tacksamheten framkom att några närstående inte kände sig tillräckligt informerade från teamet för att förstå att patienten hade kort tid kvar av livet. Det är även viktigt för teamet att veta att då närstående förstod att patienten snart skulle dö saknades information om själva döendet. Närstående frågade inte själv och kanske var det en känslosam svår fråga att ställa om inte teamet självmant tog upp detta.

Närstående var vanligtvis mycket delaktiga i omvårdnaden till patienten men ansvaret kunde också bli för tungt. Det är viktigt att teamet uppmärksammar på vilket sätt närstående vill och orkar vara delaktig men att teamet tar ansvaret och 
kan erbjuda tillräckligt med stöd. Avsaknad av nattvak gjorde att situationen nästan blev ohållbar för en närstående. Utifrån författarens erfarenhet är det inte så vanligt att närstående uttrycker behov av nattavlösning. En del närstående löser det inom familjen och turas om att vaka på natten hos den döende patienten men alla orkar inte, eller har denna möjlighet. Men teamet måste även kunna "läsa av" närstående som inte själv uttrycker detta behov och kunna erbjuda nattvak.

Teamets rutiner att fråga närstående som varit delaktiga i omvårdnaden om de vill vara med att omhänderta den avlidna väckte skuldkänslor hos en närstående. Det kan betyda att teamet inte ger tillräckligt med information till närstående. Information kan möjliggöra att närstående är bättre förberedda och det hade kanske då inte varit så negativt laddat. Författaren har inte varit med om att närstående reagerat negativt vid förfrågan men å andra sidan hade kanske inte detta framkommit utan intervjun.

Det är väsentligt för teamet att veta att efterlevandestödet var otillräckligt och närstående fick inte den uppföljning och stöd de hade behövt. Närstående saknade vårdarna i teamet som kanske inte förstod vilken betydelse de hade för närstående även efter patienten avlidit.

\section{Slutsats}

Närstående hade olika erfarenheter av det palliativa hemsjukvårdteamet och deras behov av stöd från teamet i omvårdnaden till patienten varierade. Teamet bör erbjuda närståendesamtal i anslutning till att patienten blir inskriven i den palliativa hemsjukvården och även fortlöpande under vårdtiden. Då ökas möjligheten till att identifiera närståendes behov som på så sätt kan få adekvat stöd och information. Med närståendesamtal markerar teamet att närstående är betydelsefulla i omvårdnaden till patienten. Genom att erbjuda ytterligare stöd i form av hembesök några veckor efter patienten avlidit finns möjlighet för närstående att få svar på eventuella frågor. Om "leva vidare grupper” anordnas av teamet som närstående önskade kanske fler närstående som är i behov av detta skulle delta och på så sätt underlätta sorgearbetet.

Förslag på fortsatt forskning skulle kunna vara att undersöka varför vårdform byts från palliativ hemsjukvård till hospice. 


\section{REFERENSER}

Andershed B. \& Ternestedt B. (1998) Involvement of relatives of the dying in different cultures: Involvement in the dark or in the light? Cancer Nursing 21(2), 110-116.

Andershed B. (2004) Närståendes behov i palliativ vård. I Närståendes Behov: Omvårdnad som Akademiskt Ämne, ( Östlinder G., Red.), Svensk sjuksköterskeförening, Stockholm. S. 103-112.

Beck-Friis B. \& Österberg A. (2005) Hemsjukvård- också i livets slutskede. I Palliativ Medicin, tredje upplagan (Beck- Friis B. \& Strang P., Red.), Liber AB, Stockholm. S. 203-210.

Brobäck G. \& Bertö C. (2003) How next of kin experience palliative care of relatives at home. European Journal of Cancer Care 12, 339-346.

Dahlberg K. (1997) Kvalitativa Metoder för Vårdvetare. Studentlitteratur, Lund.

Downe-Wamboldt B. (1992) Content analysis: method, applications, and issues. Health Care for Women International 13(3), 313-321.

Eckerdahl G. (2003) Kommunikation med patient, närstående och team under den palliativa processen. I Den Utmätta Tiden, Palliativ Medicin i Modern Sjukvård. Svenska läkarsällskapet och Förlagshuset Gothia AB, Växjö. S. 30-34.

Eriksson K. (1992) Broar: Introduktion i Vårdvetenskaplig Metod. Institutionen för vårdvetenskap, Åbo Akademis Förlag, Åbo.

Etiska riktlinjer för omvårdnadsforskning i Norden http://www.vardinorden.org/ssn/etikk.pdf tillgänglig 2007-10-30.

Exley C. \& Tyrer F. (2005) Bereaved carerers'views of a hospice at home service. Internatinal Journal of Palliative Nursing 11(5), 242-246.

Goldschmidt D., Schmidt L., Krasnik A., Christenesen U. \& Groenvold M. (2006) Expectations to and evaluation of a palliative home-care team as seen by patients and carers. Support Care Cancer 14, 1232-1240.

Graneheim U.H. \& Lundeman B. (2004) Qualitative content analysis in nursing research: concepts, procedures and measures to achieve trustworthiness. Nurse Education Today 24, 105-112.

Gunnars B. (1996) Sjuksköterskans roll. I Palliativ Medicin, första upplagan (Beck- Friis B. \& Strang P.,Red), Liber AB, Linköping. S. 238-246.

Holmberg L. (2006) Communication in action between family caregivers and a palliative home care team. Journal of hospice and palliative nursing 8(5), 276287. 
Hudson P., Aranda A. \& McMurray N. (2002) Intervention development for enchanged lay palliative caregiver support- the use of focus groups. European Journal of Cancer Care 11, 262-270.

Hudson P. (2004) Positive aspects and challenges associated with caring for a dying relative at home. International Journal of Palliative Nursing 10(2), 58-65.

Kvale S. (1997) Den Kvalitativa Forskningsintervjun. Lund, Studentlitteratur.

McLaghlin D., Sullivan K. \& Hasson F. (2007) Hospice at home service: the carer's perspective. Support Care Cancer 15, 163-170.

Melin-Johansson C., Axelsson B. \& Danielson E. (2007) Caregivers perceptions about the terminally ill family members quality of life. European Journal of Cancer Care 16(4), 338-345.

Millberg A., Strang P., Carlsson M. \& Börjesson S. (2003) Advanced palliative home care: next-of- kin's Perspective. Journal of Palliative Medicine 6(5), 74956.

Milberg A. \& Strang P. (2004) Exploring comprehensibility and manageability in palliative home care: An interview study of dying cancer patient's next of kin. Psycho-Oncology 13(9), 605-18.

Perreault A., Fothergill-Bourbonnais F. \& Fieset V. (2004) The experience of family members caring for a dying loved one. International Journal of Palliative Nursing 10(3), 133-43.

Rollison B. \& Carlsson M. (2002) Evaluation of advanced home care (AHC). The next-of-kin's experiences. European Journal of Oncology Nursing 6(2), 100-106.

Socialstyrelsen Vård i livets slutskede Socialstyrelsens bedömning av utvecklingen i landsting och kommuner.

http://www.socialstyrelsen.se/publicerat/2006/9371/Sammanfattning.htm Tillgänglig 2006-12-15.

Stajduhar K I. (2003) Examining the perspectives of family members involved in the delivery of palliative care at home. Journal of Palliative Care 19(1), 27-35.

Stajduhar K I. \& Davies B. (2005) Variations in and factors influencing family members'decisions for palliative home care. Palliative Medicine 19, 21-32. Travelbee J. (1971) Interpersonal Aspects of Nursing. $2^{\text {nd }}$ ed .F.A. Davis Company, Philadelphia.

Twycross R. (1999) Palliativ Vård. Studentlitteratur, Lund.

Wennman-Larsen A. \& Tishelman C. (2002) Advanced home care for cancer patients at the end of life: a qualitative study of hopes and expections of family caregivers. Scandinavian Journal of Caring Sciences 16, 240-247. 
WHO (2002) http:// http://www.who.int/cancer/palliative/definition/en// Tillgänglig 2008-01-16.

Östlinder G. (2004) Närståendes Behov: Omvårdnad som Akademiskt Ämne. Svensk Sjuksköterskeförening, Stockholm. 
Västra Frölunda 060201

Hej!

Du erbjuds härmed att delta i en uppföljning av verksamheten inom Palliativa teamet Hemsjukvården Väster i Göteborg. Studien handlar om vilka upplevelser du hade av att vara anhörigvårdare samt vilken betydelse det Palliativa teamet hade.

Inom det Palliativa teamet i Hemsjukvården Väster i Göteborg försöker vi ständigt utveckla vårt arbete. Närstående till dem som har vårdats i hemsjukvården har specifika upplevelser och erfarenheter av vad den sista tiden innebar för dem. Dessa erfarenheter är viktiga att ta tillvara. Den information vi får av dig kan kanske vara till hjälp för andra som kan komma att befinna sig i samma situation som du varit i. Målet med studien är att belysa de närståendes situation och upplevelser, samt att se vilket stöd och hjälp de fick från teamet. Vi är också intresserade av att få veta om stödet var tillräckligt. Var det något Du saknade? För att kunna genomföra detta vänder vi oss till dig som varit närstående till en person som fått vård i livets slutskede av Palliativa teamet i Hemsjukvården Väster.

Vi som arbetar med denna studie önskar intervjua dig. Om du samtycker till att delta kommer du att träffa Ingbritt Borstrand eller Carina Ekerving för en personlig intervju. Tidsåtgången beräknas till ca en timme. Vid intervjun önskar vi att du berättar om dina upplevelser under vårdtiden. Du väljer själv vad du vill prata om och vad du inte vill berätta om. Intervjun kommer att spelas in på ljudband för att senare kunna bearbetas. Banden kommer att förvaras i låst utrymme som enbart vi som arbetar med denna studie har tillgång till. När ljudbanden är bearbetade kommer de att förstöras. Inga namn eller fakta som kan röja vem du är kommer att registreras.

Deltagandet är frivilligt. Om du väljer att delta i intervjun kan du ändå när som helst ändra dig och avbryta deltagandet utan att förklara varför. Vi kommer att kontakta dig per telefon för att komma överens om när och var vi skall träffas.

Göteborg den 1 februari 2006

Ingbritt Borstrand, leg sjuksköterska

Carina Ekerving, leg sjuksköterska Hemsjukvården Väster

Tfn 031-3660500 Hemsjukvården Väster Tfn 031-3660500

Vetenskaplig ledare för projektet är Hans Ragneskog,leg sjuksköterska och universitetslektor vid Institutionen för omvårdnad Göteborgs universitet Tfn 031-7736033 